\title{
EVALUASI KESESUAIAN LAHAN KENTANG DI KAWASAN RELOKASI SIOSAR KABUPATEN KARO
}

Agustoni Tarigan ${ }^{*}$, Abdul Rauf ${ }^{2}$, Rahmawaty ${ }^{2}$

1 . Dinas Pertanian di Pemerintah Kabupaten Karo ;

2. Program Studi Pasca Sarjana Fakultas Pertanian USU, Medan

*Corresponding author: agustonitarigan@ymail.com

\begin{abstract}
Siosar relocation Region is located in the Subdistrict Merek in Karo with an altitude between 1490 - $1562 \mathrm{~m}$ above sea level. With this type of soil Andisol where land is hilly and undulating with a slope of $+37.5 \%$ and the climate type D3, leasing land from the Ministry of Environment and Forests covering an area of 144.44 ha reserved for heads of household 370 victims of the eruption of Mount Sinabung, through Decree of the Minister of the Environment life and Forestry No. SK.107 / MenLHK-II / 2015. This study aimed to evaluate the characteristics of the level of production forest land suitability for the cultivation of potatoes in the Region Siosar, to analyze the remedial efforts that need to be done in improving crop productivity and to create maps of the actual land suitability and potential land suitability potato plants. The method used was a survey method. unit of land based on soil map consists of 7 units of land analysis method is the method of comparing (matching). The results showed that the level of potential land suitability for crop potato plant (Solanum tuberosum) including marginally suitable (S3) covering an area of 156.54 ha, quite suitable (S2) covering 205.25 ha and is very suitable (S1) covering an area of 52.65 ha.Keywords: Evaluation of land suitability, production forests siosar, relocation eruption of Mount Sinabung, the cultivation of potatoes, sub brands Karo.
\end{abstract}

Keywords: Evaluation of land suitability, the cultivation of potatoes, district Karo.

\begin{abstract}
ABSTRAK
Kawasan relokasi Siosar terletak di Kecamatan Merek Kabupaten Karo dengan ketinggian antara 1490 - $1562 \mathrm{~m}$ dpl. Dengan jenis tanah Andisol dimana lahannya berbukit dan bergelombang dengan kemiringan $\pm 37,5 \%$ serta tipe iklim D3, lahan pinjam pakai dari Kementerian Lingkungan Hidup dan Kehutanan seluas 144,44 ha diperuntukkan bagi 370 Kepala Keluarga korban erupsi gunung Sinabung, melalui Surat Keputusan Menteri Lingkungan Hidup dan Kehutanan Nomor SK.107/MenLHK-II/2015. Penelitian ini bertujuan untuk mengevaluasi karakteristik tingkat kesesuaian lahan hutan produksi untuk budidaya kentang di Kawasan Siosar, untuk menganalisis usahausaha perbaikan yang perlu dilakukan dalam meningkatkan produktivitas tanaman dan ntuk membuat peta kesesuaian lahan aktual dan kesesuaian lahan potensial tanaman kentang. Metode yang di gunakan adalah metode survei. satuan unit lahan berdasarkan peta tanah terdiri dari 7 unit lahan Metode analisisnya adalah dengan metode membandingkan (matching). Hasil penelitian menunjukkan bahwa tingkat kesesuaian lahan potensial untuk tanaman tanaman kentang (Solanum tuberosum) termasuk sesuai marginal $\left(\mathrm{S}_{3}\right)$ seluas 156,54 ha, cukup sesuai $\left(\mathrm{S}_{2}\right)$ seluas 205,25 ha dan sangat sesuai $\left(\mathrm{S}_{1}\right)$ seluas 52,65 ha.
\end{abstract}

Kata Kunci : Evaluasi kesesuaian lahan , budidaya tanaman kentang, Kabupaten Karo. 


\section{PENDAHULUAN}

Kawasan relokasi Siosar merupakan kawasan ex.hutan produksi yang diberi izin pinjam pakai oleh Kementerian Lingkungan Hidup dan Kehutanan Republik Indonesia sesuai Surat Keputusan Nomor SK.107/MenLHK-II/2015. Yang diperuntukkan bagi masyarakat terdampak urupsi gunung Sinabung, selama 20 tahun seluas 414,44 ha.

Evaluasi lahan untuk keperluan perencanaan memiliki peran penting karena hampir tidak ada aktifitas yang dilakukan tanpa daya dukung lahan. Berdasarkan UU No. 24 tahun 1992 pemerintah menyarankan agar kegiatan evaluasi lahan di adakan secara luas sebagai kebijakan perencanaan kawasan indonesia, evaluasi kesesuaian lahan diharapkan memperoleh data-data karakteristik lahan yang menunjukkan sifat-sifat lahan sehingga dapat diketahui tingkat kesesuaian lahannya yang kemudian dilakukan upaya-upaya perbaikan yang sesuai dengan karakteristik lahan yang pada akhirnya akan mengoptimalkan produksi tanaman.

FAO (1976), mengemukakan bahwa untuk dapat berproduksi optimal tanaman membutuhkan persyaratan tumbuh tertentu. Disamping itu, agar dapat tumbuh dan berproduksi tinggi serta hasilnya berkualitas maka tanaman harus dibudidayakan pada lingkungan yang sesuai (Nurdin, 2011).

Kawasan hutan produksi Siosar merupakan lahan kering bekas hutan pinus yang menyisakan banyak permasalahan, yaitu ; 1) pencabutan tunggul pohon pinus, 2) masalah alelopati, 3) pemilihan komoditas, 4) lahan berlereng $(2,5-37,5 \%)$, serta 5) kemasaman dan kesuburan tanah (Agustoni, 2016). Dengan demikian penelitian ini dilakukan untuk mendukung kebijakan pemerintah dan informasi bagi masyarakat petani sehingga pengelolaan tanaman kentang dapat dilakukan secara optimal.

\section{BAHAN DAN METODE}

Secara administratif areal relokasi Siosar termasuk kedalam wilayah Desa Nagara, Kecamatan Merek. Secara geografis terletak antara $2^{\circ} 58^{\prime} 15^{\prime \prime} \mathrm{LU}$ $98^{\circ} 26^{\circ} 48^{\prime \prime} \mathrm{BT} \quad$ sampai $\quad 3^{\circ} 00^{\circ} 01^{\prime \prime} \mathrm{LU}$ $98^{\circ} 27^{\circ} 27^{\prime \prime} \mathrm{BT}$, dengan Luas areal 414,44 $\mathrm{Ha}$ (Analisis GIS, 2015). Dengan ketinggian tempat $1476-1562 \mathrm{~m} \mathrm{dpl}$ dengan kemiringan lereng 2,5 - 37,5\% (Gambar 1) , memiliki curah Hujan 1.126-1.849 mm/tahun, Temperatur ratarata tahunan $17,25{ }^{\circ} \mathrm{C}$ dan Kelembaban 89 \% (Data dari Dinas Pertanian dan Perkebunan Kabupaten Karo).

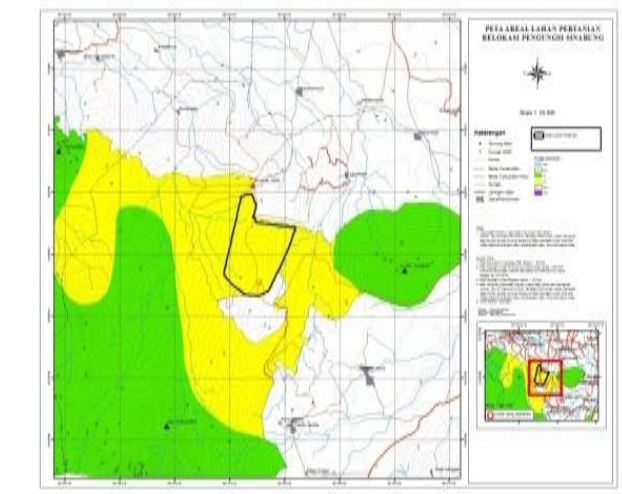

Gambar 1. Peta Lokasi Penelitian

Penelitian ini dilakukan dengan menggunakan metoda survei yang terdiri dari lima tahap yaitu persiapan, pra-survei, survei utama, analisis tanah di Laboratorium serta pengolahan data. Pengambilan sampel tanah dilakukan dengan cara pemboran pada areal satuan lahan. Dimana satuan lahan yang di pilih berdasarkan peta satuan unit penggunaan lahan. Terdapat sebanyak 25 titik sampel setelah dikompositkan (Gambar 2). Penentuan nilai karakteristik lahan untuk sampel tanah dilakukan dengan menggunakan bor tanah pada kedalaman 0-20 cm , $20-40$ dan 40-60 cm. Penentuan sifat kimia tanah dilakukan 
dengan analisa tanah di Laboratorium SOCFINDO Bangun Bandar Dolok Masihol serta penentuan Biologi tanah di Laboratorium Biologi Tanah USU Medan.

Data yang diperoleh selanjutnya diinterpretasikan ke dalam kriteria tingkat kesuburan tanah dan diinterpretasikan ke dalam kelas kesesuaian lahan menurut Sys et al(1993) dan Puslittan (1995). Proses evaluasi lahan ditentukan dengan cara matching (mencocokkan) antara karakteristik lahan dengan persyaratan tumbuh tanaman kentang yang di formulasikan dalam petunjuk teknis evaluasi lahan untuk Komoditas Pertanian (Hardjowigeno, 2007 ; Ritung et al, 2011). Pada proses matching di gunakan hukum minimum Leibig untuk menentukan faktor pembatas yang akan mempengaruhi kelas dan sub kelas kesesuaian lahannya. Hasil kesesuaian

\section{HASIL DAN PEMBAHASAN}

\section{Karakteristik lahan}

Karakteristik lahan pertanian di kawasan relokasi Siosar yang sebelumnya merupakan kawasan Hutan Produksi Pinus, dikelompok-kan ke dalam 7 (tujuh) unit lahan (land unit) dengan karakteristik lahan masing-masingnya disajikan pada Tabel 1. Dengan Jenis tanah Andisol, greatgroup Hapludands dominan yang terbentuk dari bahan induk abu vulkanis gunung Toba. Klasifikasi iklim Oldeman dengan zone iklim D3, yang mempunyai karakteristik 3 - 4 bulan basah dan 4 - 6 bulan kering secara berturut-turut, sehingga hanya mungkin melakukan satu kali tanam padi atau satu kali palawija setahun tergantung pada ketersediaan air. Zone agroekosistem ini merupakan kawasan Hutan dengan bentuk wilayah berbukit, mempunyai kemiringan lereng $\pm 37,5 \%$. Karakteristik fisik tanah yang mempengaruhi perakaran tanaman seperti tekstur, drainase dan kedalaman perakaran termasuk cukup baik yaitu lahan masing- masing komoditas tanaman ditampilkan dalam bentuk tabel kesesuaian lahan aktual dan potensial menggunakan perangkat lunak GIS. Selanjutnya dipetakan kesesuaian lahan aktual dan kesesuian lahan potensialnya.

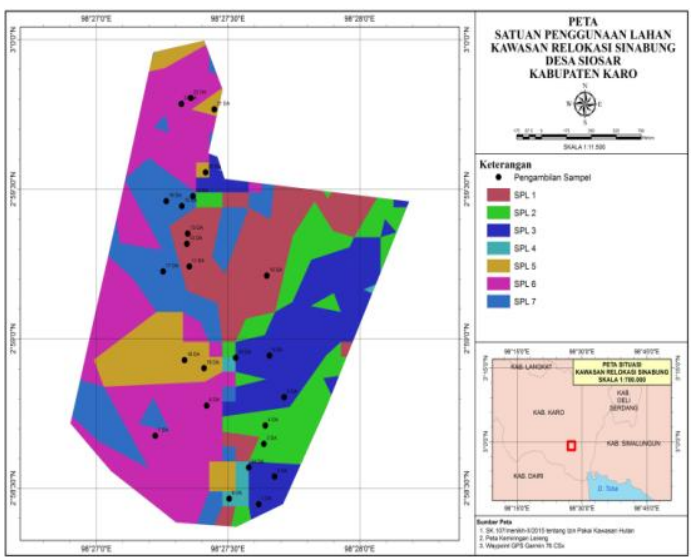

Gambar 2. Titik Pemboran Sampel Tanah

drainase tanah agak terhambat - baik, tekstur lempung liat berpasir dan kedalaman efektif hingga $>100 \mathrm{~cm}$.

Nilai $\mathrm{pH}$ tanah bervariasi dari 4.5 sampai 5.6 (masam), Nilai N-total tanah sedang sampai sangat tinggi. Nilai P- tersedia rata-rata tergolong sangat tinggi. Sedangkan $\mathrm{K}$-tukar tanah rata-rata tergolong rendah, C-Organik tergolong tinggi sehingga tidak seluruh unit lahan perlu penambahan bahan organik. Nilai KTK rata-rata sedang, dengan nilai yang sedang tanah mampu menyerap dan menyediakan unsur hara yang lebih banyak dari pada tanah dengan KTK yang lebih rendah. Kejenuhan basa di wilayah ini termasuk dalam golongan sedang. KTK dan Kejenuhan Basa merupakan indikator kesuburan kimia tanah. Tanah yang subur adalah tanah dengan kejenuhan basa tinggi sebab belum terjadi pencucian tanah yang serius. Sebaliknya, tanah dengan kejenuhan basa rendah menandakan tanah tersebut asam sehingga menghambat penyerapan unsur hara oleh akar tanaman (Indranada, 1986). 
Tabel 1. Karakteristik lahan budidaya kentang di kawasan relokasi Siosar.

\begin{tabular}{|c|c|c|c|c|c|c|c|}
\hline \multirow{2}{*}{$\begin{array}{l}\text { Karakteristik } \\
\text { Lahan }\end{array}$} & \multicolumn{7}{|c|}{ Unit Lahan } \\
\hline & 1 & 2 & 3 & 4 & 5 & 6 & 7 \\
\hline $\begin{array}{l}\text { Temperatur rata- } \\
\text { rata tahunan }\left({ }^{\circ} \mathrm{C}\right)\end{array}$ & 17,25 & 17,25 & 17,25 & 17,25 & 17,25 & 17,25 & 17,25 \\
\hline $\begin{array}{l}\text { Zona } \\
\text { Agroklimat }\end{array}$ & D3 & D3 & D3 & D3 & D3 & D3 & D3 \\
\hline Kelembaban $(\%)$ & 89 & 89 & 89 & 89 & 89 & 89 & 89 \\
\hline $\begin{array}{l}\text { Curah hujan } \\
\text { tahunan }(\mathrm{mm})\end{array}$ & 1607 & 1607 & 1607 & 1607 & 1607 & 1607 & 1607 \\
\hline $\begin{array}{l}\text { Ketinggian (m } \\
\text { dpl) }\end{array}$ & 1524 & 1524 & 1492 & 1476 & 1504 & 1490 & 1562 \\
\hline Drainase & Baik & $\begin{array}{c}\text { Agak } \\
\text { terhambat }\end{array}$ & $\begin{array}{c}\text { Agak } \\
\text { terhambat }\end{array}$ & $\begin{array}{c}\text { Agak } \\
\text { terhambat }\end{array}$ & $\begin{array}{c}\text { Agak } \\
\text { terhambat }\end{array}$ & $\begin{array}{c}\text { Agak } \\
\text { terhambat }\end{array}$ & Baik \\
\hline Tekstur & $\begin{array}{c}\text { Lempung } \\
\text { berpasir }\end{array}$ & $\begin{array}{l}\text { Lempung } \\
\text { liat berpasir }\end{array}$ & $\begin{array}{c}\text { Lempung } \\
\text { liat berpasir }\end{array}$ & $\begin{array}{c}\text { Lempung } \\
\text { berpasir }\end{array}$ & $\begin{array}{c}\text { Lempung } \\
\text { berpasir }\end{array}$ & $\begin{array}{c}\text { Lempung } \\
\text { liat berpasir }\end{array}$ & $\begin{array}{c}\text { Lempung } \\
\text { berpasir }\end{array}$ \\
\hline $\begin{array}{l}\text { Kedalaman } \\
\text { efektif }(\mathrm{cm})\end{array}$ & $>100$ & $>100$ & $>100$ & $>100$ & $>100$ & $>100$ & $>100$ \\
\hline pH Tanah & $\begin{array}{l}5,3 \\
(\mathrm{M})\end{array}$ & 5,6 (AM) & $\begin{array}{l}4,8 \\
\text { (M) }\end{array}$ & $\begin{array}{l}4,9 \\
(\mathrm{M})\end{array}$ & $\begin{array}{l}5,1 \\
(\mathrm{M})\end{array}$ & $\begin{array}{l}5,1 \\
\text { (M) }\end{array}$ & $\begin{array}{l}5,2 \\
(\mathrm{M})\end{array}$ \\
\hline C-organik (\%) & $\begin{array}{c}6,6 \\
(\mathrm{ST})\end{array}$ & $\begin{array}{l}3,1 \\
(\mathrm{~T})\end{array}$ & $\begin{array}{l}2,1 \\
(\mathrm{~S})\end{array}$ & $\begin{array}{l}2,4 \\
(\mathrm{~S})\end{array}$ & $\begin{array}{l}3,4 \\
(\mathrm{~T})\end{array}$ & $\begin{array}{l}3,9 \\
(\mathrm{~T})\end{array}$ & $\begin{array}{c}4 \\
(\mathrm{~T})\end{array}$ \\
\hline $\mathrm{N}$-total (\%) & $0,76(\mathrm{ST})$ & $\begin{array}{r}0,58 \\
(\mathrm{~T}) \\
\end{array}$ & $\begin{array}{r}0,26 \\
(\mathrm{~S}) \\
\end{array}$ & $\begin{array}{l}0,24 \\
(\mathrm{~S}) \\
\end{array}$ & $\begin{array}{c}0,63 \\
(\mathrm{~T}) \\
\end{array}$ & $\begin{array}{l}0,58 \\
(\mathrm{~T})\end{array}$ & $\begin{array}{l}0,76 \\
\text { (ST) } \\
\end{array}$ \\
\hline $\begin{array}{l}\mathrm{P}_{2} \mathrm{O}_{5} \text { Bray II } \\
(\mathrm{mg} / 100 \mathrm{~g})\end{array}$ & $5,74(\mathrm{ST})$ & $4,61(\mathrm{ST})$ & $\begin{array}{r}2,25 \\
(\mathrm{~S})\end{array}$ & $\begin{array}{l}2,29 \\
(\mathrm{~S})\end{array}$ & $3,84 \quad(\mathrm{ST})$ & 4,03 (ST) & $8,91 \quad(\mathrm{ST})$ \\
\hline Kej.Basa (\%) & $64.95(\mathrm{~T})$ & $72.90(\mathrm{~T})$ & $49,70(\mathrm{~S})$ & 35,93 (R) & $\begin{array}{l}44,87 \\
(\mathrm{~S}) \\
\end{array}$ & 44,12 (S) & $\begin{array}{l}45,92 \\
(\mathrm{~S}) \\
\end{array}$ \\
\hline KTK (me/100g) & $20,89(\mathrm{~S})$ & 14,47 (R) & $20,15(\mathrm{~S})$ & $\begin{array}{c}27,99 \\
(\mathrm{~T})\end{array}$ & $\begin{array}{c}23,73 \\
(\mathrm{~S})\end{array}$ & $23,90(\mathrm{~S})$ & $\begin{array}{l}24,37 \\
(\mathrm{~S})\end{array}$ \\
\hline $\begin{array}{l}\text { K-tukar (me/100 } \\
\text { g) }\end{array}$ & $\begin{array}{r}0,26 \\
(\mathrm{R}) \\
\end{array}$ & $\begin{array}{l}0,18 \\
(\mathrm{R})\end{array}$ & $\begin{array}{c}0,18 \\
(\mathrm{R})\end{array}$ & $\begin{array}{r}0,15 \\
(\mathrm{R}) \\
\end{array}$ & $\begin{array}{l}0,26 \\
(\mathrm{R}) \\
\end{array}$ & $\begin{array}{r}0,19 \\
(\mathrm{R}) \\
\end{array}$ & $\begin{array}{r}0,13 \\
(\mathrm{R}) \\
\end{array}$ \\
\hline $\begin{array}{l}\begin{array}{l}\text { Ca-tukar } \\
(\mathrm{me} / 100 \mathrm{~g})\end{array} \\
\end{array}$ & $12,68(\mathrm{~T})$ & $\begin{array}{l}9,29 \\
(\mathrm{~S}) \\
\end{array}$ & $\begin{array}{r}9,33 \\
(\mathrm{~S}) \\
\end{array}$ & $\begin{array}{l}9,44 \\
(\mathrm{~S})\end{array}$ & $\begin{array}{l}10,1 \\
(\mathrm{~S})\end{array}$ & $10,23(\mathrm{~S})$ & $\begin{array}{c}10,08 \\
(\mathrm{~S}) \\
\end{array}$ \\
\hline $\begin{array}{l}\begin{array}{l}\text { Mg-tukar } \\
(\mathrm{me} / 100 \mathrm{~g})\end{array} \\
\end{array}$ & $\begin{array}{c}0,66 \\
(\mathrm{R}) \\
\end{array}$ & $\begin{array}{c}0,54 \\
(\mathrm{R}) \\
\end{array}$ & $\begin{array}{c}0,55 \\
(\mathrm{R}) \\
\end{array}$ & $0,38(\mathrm{SR})$ & $\begin{array}{l}0,37 \\
(\mathrm{SR}) \\
\end{array}$ & $\begin{array}{r}0,51 \\
(\mathrm{R}) \\
\end{array}$ & $\begin{array}{l}0,18 \\
\text { (SR) } \\
\end{array}$ \\
\hline $\begin{array}{l}\text { Na-tukar } \\
(\mathrm{me} / 100 \mathrm{~g})\end{array}$ & $0,00(\mathrm{SR})$ & $\begin{array}{l}0,14 \\
(\mathrm{R})\end{array}$ & 0,08 (SR) & $\begin{array}{l}0,11 \\
(\mathrm{R})\end{array}$ & $\begin{array}{r}0,13 \\
(\mathrm{R})\end{array}$ & 0,01 (SR) & $\begin{array}{c}0 \\
(\mathrm{SR})\end{array}$ \\
\hline Lereng (\%) & 2,5 & 3 & 6 & 3 & 22,5 & 37,5 & 3 \\
\hline $\begin{array}{l}\text { Batuan } \\
\text { dipermukaan } \\
(\%)\end{array}$ & 0 & 0 & 0 & 0 & 0 & 0 & 0 \\
\hline $\begin{array}{l}\text { Singkapan } \\
\text { batuan }(\%)\end{array}$ & 0 & 0 & 0 & 0 & 0 & 0 & 0 \\
\hline Bahaya Banjir & F0 & F0 & F0 & F0 & F0 & F0 & F0 \\
\hline $\begin{array}{l}\text { Total Mikroba } \\
\text { (cfu) }\end{array}$ & $3,0 \times 10^{7}$ & $2,5 \times 10^{7}$ & $4,5 \times 10^{7}$ & $1,5 \times 10^{7}$ & $1,5 \times 10^{7}$ & $4,5 \times 10^{6}$ & $2,5 \times 10^{8}$ \\
\hline Keterangan: ST & sangat & & $\begin{array}{l}\mathrm{R}=\text { rend } \\
\mathrm{F} 0=\text { tida }\end{array}$ & ada banjir & & $\begin{array}{l}=\text { sedang } \\
=\text { masam }\end{array}$ & \\
\hline
\end{tabular}

\section{Kelas Kesesuaian Lahan Pertanian Relokasi Sinabung}

Penilaian kelas kesesuaian lahan pada Kawasan Hutan Produksi Siosar yang akan dijadikan lahan budidaya kentang bagi pengungsi erupsi gunung Sinabung dilakukan pada setiap unit lahan.

\section{Kesesuaian lahan untuk tanaman Kentang (Solanum tuberosum)}

Dari Tabel 2. karakteristik ketersediaan hara $\mathrm{K}_{2} \mathrm{O}$ tanah dan kemiringan lereng pada areal pertanian relokasi Siosar untuk tanaman kentang (Solanum tuberosum) tergolong rendah, dan bukanlah faktor pembatas utama 
karena masih bisa dilakukan pengelolaan dengan penambahan unsur hara ke dalam tanah dan melakukan tindakan konservasi berupa pembuatan teras maupun penanaman sejajar kontur serta melakukan system pertanaman zigzag sehingga unsur hara dan tanah tidak mudah tercuci ketika terjadi curah hujan yang cukup tinggi. Yang menjadi faktor pembatas utama dalam penilaian kelas kesesuaian lahan untuk tanaman Kentang
(Solanum tuberosum) adalah media perakaran berupa tekstur tanah, dikarenakan tekstur tanah tidak akan berubah dalam waktu yang singkat, contohnya tekstur pasir sulit dirubah menjadi lempung atau tekstur liat sulit dirubah menjadi pasir. Hal ini didukung oleh Rayes (2007) yang menyatakan bahwa dalam evaluasi lahan dengan faktor media perakaran berupa tekstur tidak dapat dilakukan usaha perbaikan.

Dari hasil analisis yang di peroleh dapat dilihat pada Tabel rekapitulasi hasil penilaian lahan berikut ini :

Tabel 2. Rekapitulasi kesesuaian lahan dan Upaya perbaikan yang dilakukan pada budidaya tanaman Kentang (Solanum tuberosum).

\begin{tabular}{|c|c|c|c|}
\hline Land Unit & KLA & Perkiraan Usaha Perbaikan & KLP \\
\hline Unit lahan 1 & $\begin{array}{l}\mathrm{S}_{2}-\mathrm{rc}, \\
\mathrm{nr}\end{array}$ & $\begin{array}{l}\text { - Pengapuran 2,1 ton } \mathrm{CaCO}_{3} / \mathrm{ha} \\
\text { - Pemupukan } 49 \mathrm{~kg} \mathrm{~K}_{2} \mathrm{O} / \mathrm{ha} \text { atau } 82,33 \mathrm{~kg} \mathrm{KCl} / \mathrm{ha}\end{array}$ & $\mathrm{S}_{2}-\mathrm{rc}$ \\
\hline Unit lahan 2 & $\begin{array}{l}S_{2}-n r \\
\text { na,eh }\end{array}$ & $\begin{array}{l}\text { - Pemupukan } 70 \mathrm{~kg} \mathrm{~K}_{2} \mathrm{O} / \mathrm{ha} \text { atau } 117 \mathrm{~kg} \mathrm{KCl} / \mathrm{ha} \\
\text { - Pemberian B.Organik } 5.34 \text { ton/ha atau } 25 \mathrm{ton} / \mathrm{ha} \text { pupuk organik } \\
\text { - Penanaman sejajar kontur, dan system pertanaman Zigzag. }\end{array}$ & $\overline{\mathbf{S}_{1}}$ \\
\hline Unit lahan 3 & $\mathbf{S}_{3}-\mathbf{n r}$ & $\begin{array}{l}\text { - Pengapuran } 2,1 \text { ton } \mathrm{CaCO}_{3} / \mathrm{ha} \\
\text { - Pemupukan } 270 \mathrm{~kg} / \mathrm{ha} \mathrm{P}_{2} \mathrm{O}_{5} \text { atau } 750 \mathrm{~kg} / \mathrm{ha} \mathrm{SP} 36 \\
\text { - Pemupukan } 70 \mathrm{~kg} \mathrm{~K} \mathrm{O}_{2} \mathrm{O} / \mathrm{ha} \text { atau } 117 \mathrm{~kg} \mathrm{KCl} / \mathrm{ha}\end{array}$ & $\mathbf{S}_{2}-\mathrm{nr}$ \\
\hline Land unit 4 & $\mathbf{S}_{3}$-nr & $\begin{array}{l}\text { - Pengapuran 2,1 ton } \mathrm{CaCO}_{3} / \mathrm{ha} \\
\text { - Pemupukan } 267 \mathrm{~kg} / \mathrm{ha} \mathrm{P}_{2} \mathrm{O}_{5} \text { atau } 742 \mathrm{~kg} / \mathrm{ha} \mathrm{SP} 36 \\
\text { - Pemupukan } 78 \mathrm{~kg} \mathrm{~K} \mathrm{~K}_{2} \mathrm{O} / \mathrm{ha} \text { atau } 130 \mathrm{~kg} \mathrm{KCl} / \mathrm{ha} \\
\text { - Penanaman sejajar kontur, dan system pertanaman Zigzag. }\end{array}$ & $\begin{array}{c}\mathbf{S}_{2} \text {-rc, } \\
\text { nr }\end{array}$ \\
\hline Unit lahan 5 & N-eh & $\begin{array}{l}\text { - Pengapuran } 2,1 \text { ton } \mathrm{CaCO}_{3} / \mathrm{ha} \\
\text { - Pemupukan } 49 \mathrm{~kg} \mathrm{~K} \mathrm{~K}_{2} \mathrm{O} / \mathrm{ha} \text { atau } 82,33 \mathrm{~kg} \mathrm{KCl} / \mathrm{ha} \\
\text { - Pembuatan teras maupun penanaman sejajar kontur, dan system } \\
\text { pertanaman Zigzag. }\end{array}$ & $\mathbf{S}_{\mathbf{3}^{-} \text {-eh }}$ \\
\hline Unit lahan 6 & N-eh & $\begin{array}{l}\text { - Pengapuran } 2,1 \text { ton } \mathrm{CaCO}_{3} / \mathrm{ha} \\
\text { - Pemupukan } 68 \mathrm{~kg} \mathrm{~K} \mathrm{~K}_{2} \mathrm{O} / \mathrm{ha} \text { atau } 112,67 \mathrm{~kg} \mathrm{KCl} / \mathrm{ha} \\
\text { - Pembuatan teras maupun penanaman sejajar kontur, dan system } \\
\text { pertanaman Zigzag. }\end{array}$ & $\mathbf{S}_{3}$-eh \\
\hline Unit lahan 7 & $\begin{array}{l}\text { S }_{2} \text {-rc, } \\
\text { nr,na, } \\
\text { eh }\end{array}$ & $\begin{array}{l}\text { - Pengapuran 2,1 ton } \mathrm{CaCO}_{3} / \mathrm{ha} \\
\text { - Pemupukan } 83 \mathrm{~kg} \mathrm{~K} \text { O/ha atau } 138,67 \mathrm{~kg} \mathrm{KCl} / \mathrm{ha} \\
\text { - Penanaman sejajar kontur, dan system pertanaman Zigzag. }\end{array}$ & $\mathbf{S}_{2}-\mathrm{rc}$ \\
\hline
\end{tabular}

Keterangan : KLA = Kesesuaian Lahan Aktual KLP = Kesesuaian Lahan Potensial

Dari hasil analisis GIS diperoleh luas kesesuaian lahan aktual dan potensial pada areal pertanian relokasi Sinabung untuk tanaman Kentang (Solanum tuberosum) (Tabel 3) dan peta kesesuaian lahannya disajikan pada Gambar 3 dan 4. 
Tabel 3. Luas kesesuaian lahan untuk tanaman Kentang (Solanum tuberosum)

\begin{tabular}{ccccc}
\hline Unit Lahan & $\begin{array}{c}\text { Kesesuaian lahan } \\
\text { aktual }\end{array}$ & $\begin{array}{c}\text { Kesesuaian lahan } \\
\text { potensial }\end{array}$ & Luas (Ha) & Persenatse (\%) \\
\hline 1 & $\mathrm{~S} 2(\mathrm{rc}, \mathrm{nr})$ & $\mathrm{S} 2(\mathrm{rc})$ & 72,17 & 17,41 \\
\hline 2 & $\mathrm{~S} 2(\mathrm{nr}, \mathrm{na}, \mathrm{eh})$ & $\mathrm{S} 1$ & 52,65 & 12,70 \\
\hline 3 & $\mathrm{~S} 3(\mathrm{nr})$ & $\mathrm{S} 2(\mathrm{nr})$ & 64,49 & 15,56 \\
\hline 4 & $\mathrm{~S} 3(\mathrm{nr})$ & $\mathrm{S} 2(\mathrm{rc}, \mathrm{nr})$ & 63,85 & 15,41 \\
\hline 5 & $\mathrm{~N}(\mathrm{eh})$ & $\mathrm{S} 3(\mathrm{eh})$ & 37,27 & 8,99 \\
\hline 6 & $\mathrm{~N}(\mathrm{eh})$ & $\mathrm{S} 3(\mathrm{eh})$ & 119,27 & 28,78 \\
\hline 7 & $\mathrm{~S} 2(\mathrm{rc}, \mathrm{nr}, \mathrm{na}, \mathrm{eh})$ & $\mathrm{S} 2(\mathrm{rc})$ & 4,74 & 1,14 \\
\hline & Total & & $\mathbf{4 1 4 , 4 4}$ & $\mathbf{1 0 0 , 0 0}$ \\
\hline
\end{tabular}

Sumber : Hasil analisis GIS

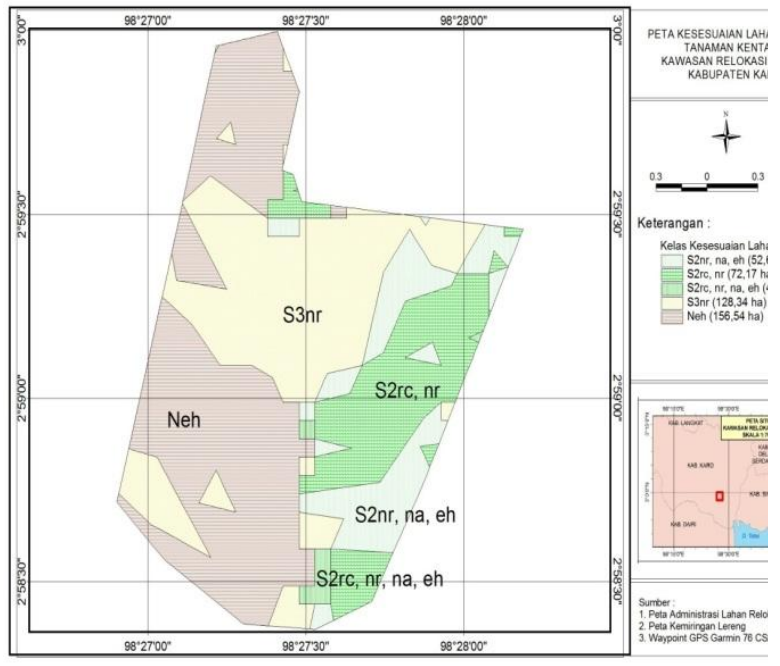

Gambar 3. Peta Kesesuaian lahan aktual tanaman Kentang (Solanum tuberosum) di lahan pertanian relokasi Sinabung, Kabupaten Karo

\section{SIMPULAN}

Kelas kesesuaian lahan aktual untuk budidaya tanaman kentang termasuk kelas tidak sesuai / Neh seluas 156,54 ha dan kelas kesesuaian lahan potensial termasuk kelas sesuai marginal / $\mathrm{S}_{3}$ eh seluas 156,54 ha serta terdapat kelas sangat sesuai / $\mathrm{S}_{1}$ seluas 52,65 ha pada unit lahan 2, dimana faktor pembatas yang tidak dapat dilakukan upaya perbaikan adalah tekstur tanah,

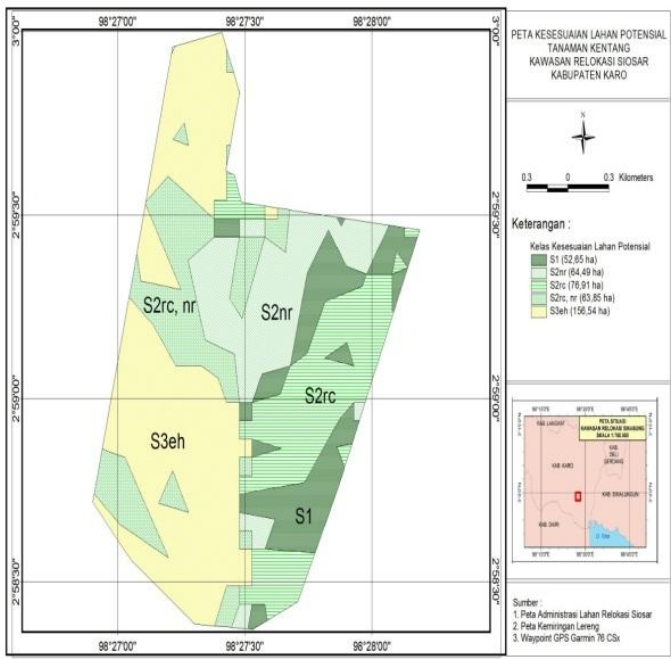

Gambar 4. Peta Kesesuaian lahan potensial tanaman Kentang (Solanum tuberosum)

di lahan pertanian relokasi Sinabung, Kabupaten Karo

sedangkan faktor pembatas seperti retensi hara, ketersedian hara, ketersediaan air, dan bahaya erosi dapat dilakukan upaya perbaikan berupa : (1). Pemberian bahan organik, pengapuran, dan pemupukan yang disesuaikan dengan hasil uji tanah pada masing-masing unit lahan, dan (2). Pembuatan saluran drainase, penanaman dengan sistem zigzag, sejajar kontur, dan pembuatan teras/gludan. 


\section{DAFTAR PUSTAKA}

Djaenudin, D; Marwan, Subagyo dan A. Hidayat. 2003. Petunjuk Teknis Evaluasi Lahan Untuk Komoditas Pertanian. Balai Penelitian Tanah, Puslitbangtanah, Badan Penelitian dan Pengembangan Pertanian. Bogor. 154 hal.

Douglas Horton, 1987. Potatoes. Production, Marketting, and Programs for Developing Countries. Westview Press (Boulder). ITPublications (London)

Food And Agriculture Organization Of The United Nations (FAO), 1976, a framework for land evaluation, soil resources development and concervation secvice land and water development division, Soils Bulletin, 32

H. Sarwono Hardjowigeno. 2003. Ilmu Tanah. Akademika Pressindo. Jakarta.

Indranada, H. K. 1986. Pengelolaan Kesuburan Tanah. Jakarta: PT Bina Aksara

Mega, I. N. Dibia, I.G.P. Ratna dan T.B. Kusmiyarti. 2010. Klassifikasi Tanah dan Kesesuaian Lahan. Fakultas Pertanian, Universitas Udayana, Denpasar. 145 hal

Mubekti. 2012. Evaluasi Karakteristik dan Kesesuaian Lahan untuk Komoditi Unggulan Perkebunan : Studi Kasus Kabupaten Kampar. Jurnal Teknik Lingkungan. Jakarta.

Oldeman, L.R; 1975. The. Agrodimatic Map of Java and Madura, Bogor. Contributions from the Central Research Institute for Agriculture.

Puslittan, Badan Litbangtan, Kementerian Pertanian Republik Indonesia, 1995. Evaluasi Kesesuaian Lahan.

Rauf. A, Laudin Musa, Muklis. 2006. Fundamentals of soil seince. Bahan kuliah dasar ilmu tanah. USU Medan.
Ritung S, K.Nugroho, A.Mulyani dan E.Suryani. 2011. Petunjuk teknis evaluasi lahan untuk komoditas pertanin (Edisi revisi). Balai Besar Penelitian dan Pengembagan Sumberdaya Lahan, Badan Penelitian dan Pengembangan Pertanian, Bogor. 168 hal.

Rukmana. 1997. Kentang budidaya dan pasca panen, Kanasius. Yogyakarta

Samadi, B. 1997. Usahatani Kentang. Kanisius. Yogyakarta.

Setijono, 1982. dalam M.Madjid B. Damanik, Bachtiar Effendi Hasibuan, Fauzi Sarifuddin dan Hamidah Hanum, 2011. Kesuburan Tanah dan Pemupukan. USU Press. Medan.

Subandi dan Zubachtirodin. 2008. Peningkatan efesiensi pupuk N,P,K dan Produktivitas jagung pada lahan kering ultisol kalimantan selatan. Balai penelitian tanaman serealia. Jurnal peneltian tanaman pangan. Vol. 27 no 1

Sukarman ,Erna Suryani, Ai Dariah, Markus Anda, Etty PratiwiNeneng L. Nurida Sutono, Dedi Erfandi, A. Kasno Irsal Las 2015 Petunjuk Teknis Penanganan Lahan elokasi Pengungsi Sinabung di Siosar, Kabupaten Karo, Sumatera Utara: Balai Besar Litbang Sumberdaya Lahan Pertanian. Badan Penelitian dan Pengembangan Pertanian. Bogor.

Suprapto, 2014. Laporan akhir kajian dampak erupsi gunung Sinabung terhadap sumber daya lahan dan sosial ekonomi untuk pengembangan pertanin. Balai Besar Penelitian dan Pengembangan Sumber Daya Lahan Pertanian. Badan Peneliatian dan Pengembangan Pertanian, Bogor. 
Surat Keputusan Menteri Lingkungan Hidup dan Kehutanan Nomor SK.107/MenLHK-II/2015, tentang ijin pinjam pakai kawasan hutan produksi Siosar untuk lahan pertanian bagi korban erupsi gunung Sinabung, Kabupaten Karo

Slamet Susanto.1997. Budidaya tanaman Kentang.http;//mfile.narotama.ac. id.
Sys, C. ,E. Van Ranst, J. Debaveye, and F. Beernaert.1993. Land Evaluation. Crop Requirements Part III. Agricultural Publication No.7. General Administration for Development Corp. 1050 Brussels- Belgium.

Wien, H.C. 1997. The physiology of vegetable crops. Cab. International 